\title{
Oxidized LDL Cholesterol Antibody Measurement
}

National Cancer Institute

\section{Source}

National Cancer Institute. Oxidized LDL Cholesterol Antibody Measurement. NCI

Thesaurus. Code C119288.

The determination of the amount of oxidized low density lipoprotein cholesterol antibody in a biological specimen. 